OPEN ACCESS

Edited by:

Esaki M. Shankar

Central University of Tamil Nadu, India

Reviewed by:

Samudi Chandramathi,

University of Malaya, Malaysia

Hridayesh Prakash,

Amity University, India

*Correspondence:

Biao Ren

renbiao@scu.edu.cn

Xuedong Zhou

zhouxd@scu.edu.cn

Specialty section:

This article was submitted to

Microbial Immunology,

a section of the journal

Frontiers in Microbiology

Received: 13 January 2021

Accepted: 31 May 2021

Published: 21 June 2021

Citation:

Zhou Y, Cheng L, Lei YL, Ren B and Zhou $X$ (2021) The Interactions

Between Candida albicans and Mucosal Immunity.

Front. Microbiol. 12:652725. doi: 10.3389/fmicb.2021.652725

\section{The Interactions Between Candida albicans and Mucosal Immunity}

\author{
Yujie Zhou ${ }^{1,2}$, Lei Cheng ${ }^{1}$, Yu L. Lei ${ }^{3}$, Biao Ren ${ }^{1 *}$ and Xuedong Zhou ${ }^{1 *}$ \\ 1 State Key Laboratory of Oral Diseases, West China Hospital of Stomatology, National Clinical Research Center for Oral \\ Diseases, Sichuan University, Chengdu, China, ${ }^{2}$ Guanghua School of Stomatology, Hospital of Stomatology, Sun Yat-sen \\ University, Guangzhou, China, ${ }^{3}$ Department of Periodontics and Oral Medicine, University of Michigan School of Dentistry, \\ University of Michigan Rogel Cancer Center, University of Michigan, Ann Arbor, MI, United States
}

Mucosa protects the body against external pathogen invasion. However, pathogen colonies on the mucosa can invade the mucosa when the immunosurveillance is compromised, causing mucosal infection and subsequent diseases. Therefore, it is necessary to timely and effectively monitor and control pathogenic microorganisms through mucosal immunity. Candida albicans is the most prevalent fungi on the mucosa. The C. albicans colonies proliferate and increase their virulence, causing severe infectious diseases and even death, especially in immunocompromised patients. The normal host mucosal immune defense inhibits pathogenic C. albicans through stepwise processes, such as pathogen recognition, cytokine production, and immune cell phagocytosis. Herein, the current advances in the interactions between C. albicans and host mucosal immune defenses have been summarized to improve understanding on the immune mechanisms against fungal infections.

Keywords: Candida albicans, mucosa, immune cell, immune recognition, immune escape

\section{INTRODUCTION}

The mucosa serves as the first line of defense against external stimuli, such as toxins, cytokines, and pathogens (Awad et al., 2017). The mucosa is typically warm and humid, making it an ideal environment for micro-organism colonization and survival, including bacteria, fungi, and viruses (Hillman et al., 2017). Notably, the dynamic balance between the mucosa and microorganisms is essential for the health of the host (Grice and Segre, 2011). Some conditional microbes can transform from common ecological to the pathogenic state depending on the condition of the body and immune function (Belkaid and Hand, 2014). The mucosal immunity monitors and regulates microbe balance to inhibit and control the occurrence of infections (Hooper et al., 2012; Belkaid and Hand, 2014).

Fungi, mainly Candida, can commensally colonize the mucosal surface (Williams and Lewis, 2011; Kühbacher et al., 2017). Several Candida species colonize the mucosa, including C. albicans, Candida glabrata, Candida tropicalis, Cryptococcus neoformans, Candida krusei, etc. However, C. albicans is the most prevalent fungus (Pincus et al., 2007). As a conditional pathogen, C. albicans acts as a symbiotic fungus when immunity is normal and transforms into the pathogenic state when an immune disorder occurs. Besides, C. albicans can create ideal survival and colonization conditions for other bacteria, with such coinfections leading to more severe infectious diseases and drug resistance (Arvanitis and Mylonakis, 2015; Krüger et al., 2019). Blood infections caused by a combination of C. albicans and Staphylococcus have a high mortality rate (Kong et al., 2016; Carolus et al., 2019). 
The detection rate of $C$. albicans in the oral cavity is associated with pneumonia severity, especially ventilatorassociated pneumonia (VAP). Therefore, maintaining good oral health can decrease the ICU pneumonia rate (Souza et al., 2017). Polysaccharide secretion from C. albicans causes the development of Streptococcus mutans biofilms in the mouth, thus increasing dental caries (Khoury et al., 2020). The biofilms combined with $C$. albicans and Streptococcus gordonii have high resistance to antibacterial and antifungal antibiotics (Montelongo-Jauregui et al., 2019). A study showed that infections caused by Staphylococcus aureus combined with $C$. albicans are highly resistant to antibiotics (Peters and Noverr, 2013).

C. albicans exist in yeast form on the mucosal surface in its symbiotic state and as a hypha in a pathogenic state. Therefore, C. albicans hypha is the main pathogenic virulence factor that invades the host, causing local mucosal infection (Williams and Lewis, 2011). C. albicans mainly causes candidal leukoplakia, redness, and swelling of the mucosa in the oral cavity (Patil et al., 2015). C. albicans can also cause oral denture stomatitis if the host wears dentures for a long time (Gleiznys et al., 2015). C. albicans causes median rhomboid glossitis of the tongue if the host has smoking habits (Bihari et al., 2014). Furthermore, the gastrointestinal mucosa, has numerous C. albicans colonies, which can be an important reserve pool for infection to spread in the human body (Kaufman and Fairchild, 2004). It can also cause candidemia through blood-borne diffusion in severe cases (Iliev et al., 2012; Patricio et al., 2019). C. albicans can also form a biofilm on the human mucosa surface, reducing drug and host immune system efficacies (Nobile and Johnson, 2015).

The human mucosal immunity protects the body at the initial stage through various monitoring and defense pathways, including the initial recognition and response, activation of appropriate immune defense responses, thus limiting fungal infections. This article summarizes the current advances in the interaction mechanisms between host mucosal immunity and $C$. albicans to understand the immune response to fungal infections better. This study also provides possible antifungal targets against C. albicans infection.

\section{RECOGNITION OF VARIOUS CELLULAR COMPONENTS OF C. ALBICANS BY HOST IMMUNITY}

The C. albicans cell wall can be divided into two layers, the outer and inner layers. The outer layer is mainly composed of C-linked glycoproteins such as mannan (80-90\%). The inner layer contains chitin, $\beta$-1,3-glucan, and $\beta$-1,6-glucan (Shibata et al., 2007; Lowman et al., 2014). The host cells can recognize the components of the $C$. albicans cell wall through various pattern recognition receptors (PRR) on their cell surface (Figure 1) (the first step in activating human immunity). Many PRR families, including Toll-like receptors (TLR), C-type lectin receptors (CLR), NOD-like receptors (NLR), and RIG-1-like receptors (RLR), are involved in the fungal recognition process (Jang et al., 2015; Table 1).

\section{Chitin}

Chitin is located in the innermost layer of the C. albicans cell wall. Chitin induces interleukin 10 (IL-10) production in neutrophils and macrophages through a nucleotide-binding oligomerization domain with protein 2 (NOD2)-dependent pathway to inhibit host pro-inflammatory response during fungal infection (Davidson et al., 2018; Patricia et al., 2019). I Besides, TLR9 recognizes chitin, which induces several anti-inflammatory cytokines, such as IL-10 (Wagener et al., 2014), that maintain a balanced immune response (Salazar and Brown, 2018).

\section{Mannan}

Mannan and mannoprotein are key components of the Candida spp. cell wall and are recognized by various CLRs, including mannose receptor, Dectin-2, dendritic cell (DC) specific ICAM3 capture non-integrin (DC-SIGN), and MINCLE (Cambi et al., 2008; van de Veerdonk et al., 2009; Yamasaki et al., 2009; Saijo et al., 2010). The mannose receptor is found on the macrophage surface and binds to the Candida N-mannan (Porcaro et al., 2003; Netea et al., 2008), thus promoting cytokine production, especially IL-17 (van de Veerdonk et al., 2009). Dectin-2 is mainly expressed in DCs, macrophages, and neutrophils, and can recognize Candida $\alpha$-mannan. Dectin-2 also regulates $\mathrm{T}$ helper cell 17 (Th 17) response, ROS production, and phagocytosis (Wells et al., 2008; Saijo et al., 2010; Saijo and Iwakura, 2011; Thompson et al., 2019). C-SIGN, expressed in DC cells and macrophages, can recognize N-mannan in Candida spp. DCSIGN activation promotes Th cell activation and differentiation by inducing cytokine production (Ramirez-Ortiz and Means, 2012; Goyal et al., 2018; Speakman et al., 2020). Mannan can also be recognized by TLRs, such as TLR2, TLR4, and TLR6. Furthermore, activation of downstream pathways promotes the expression of pro-inflammatory cytokines during Candida infection (Mogensen, 2009).

\section{$\beta$-Glucan}

$\beta$-glucans, including $\beta$-1,3- and $\beta$-1,6-glucans, are essential antigen components in the $C$. albicans cell wall (Chaffin et al., 1998). $\beta$-glucan is covered by the outermost mannoproteins in the yeast phase, thus preventing $C$. albicans recognition by the body immunity (Garcia-Rubio et al., 2019). The C. albicans yeast and hyphae have structurally different $\beta$-glucans (Lowman et al., 2014). The C. albicans in budding or hyphal forms expose $\beta$-glucan during yeast phase to hyphal phase transition (Davis et al., 2014), which the CLR mainly recognizes. Dectin-1 is the most studied $\beta$-glucan receptor (Brown et al., 2002; Batbayar et al., 2012). Dectin-1 is expressed primarily on monocytes and macrophages and induces cytokine release and phagocytosis of fungi (Goyal et al., 2018). Dectin-1 also promotes the recognition response of TLR2 and TLR4 (Trinchieri and Sher, 2007; OliveiraNascimento et al., 2012), which are associated with cell wall mannan recognition. Dectin-1 signaling pathway can also inhibit the overactivation of neutrophil extracellular traps (NETs) during fungal infections, preventing uncontrolled tissue damage during the immune response (Branzk et al., 2014). $\beta$-glucan can also be recognized by complement receptor 3 (CR3), which is essential 


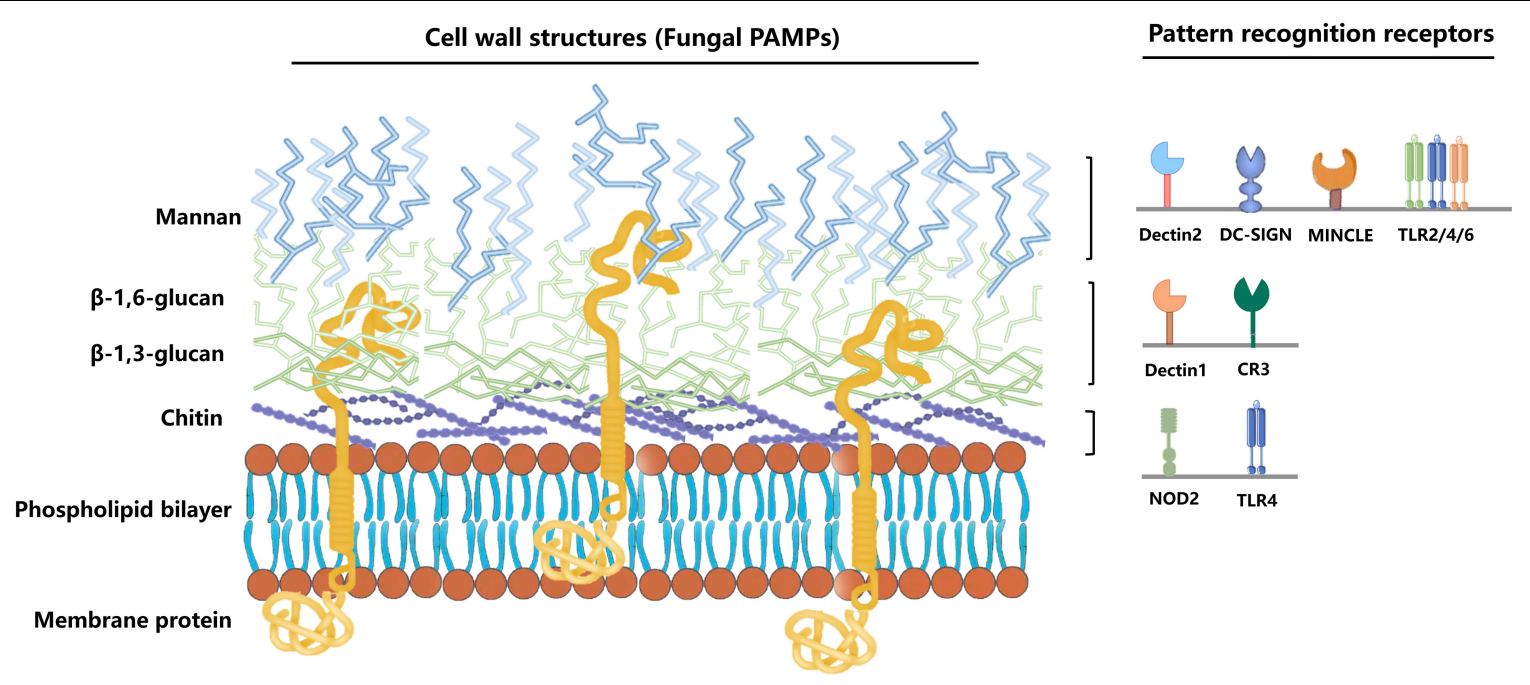

FIGURE 1 | Immune cells recognize different $C$. albicans PAMPs. C. albicans pathogen-associated molecular patterns (PAMPs) bind to different pathogen-recognition receptors (PRRs) of the host cell to induce immunity via the fungal cell. The outer cell wall layer is mainly composed of C-linked glycoproteins, such as mannan (80-90\%). The inner cell wall contains highly immunogenic chitin, $\beta-1,3-$ glucan, and $\beta-1,6-$ glucan. Mannan can be recognized by the Dectin-2, DC-SIGN, MINCLE, and TLR2/4/6. Besides, $\beta$-glucan and chitin can be recognized by Dectin-1, CR3, and NOD2, TLR4, respectively.

in the recognition, phagocytosis, and killing of C. albicans in neutrophils (van Bruggen et al., 2009; Gazendam et al., 2014).

\section{INTERACTION BETWEEN C. ALBICANS AND HOST MUCOSAL IMMUNE CELLS}

The oral mucosa structure is similar to that of the skin, composed of the epithelium and lamina propria. The epithelium

TABLE 1 | Pattern recognition receptors that sense fungal-associated PAMPs.

\begin{tabular}{|c|c|c|c|}
\hline \multicolumn{2}{|c|}{$\begin{array}{l}\text { Pathogen-recognition } \\
\text { receptors (PRRs) }\end{array}$} & \multirow{2}{*}{$\begin{array}{c}\text { Cell type } \\
\text { expressing } \\
\text { PRRs } \\
\begin{array}{c}\text { Macrophage } \\
\text { DCs }\end{array}\end{array}$} & \multirow{2}{*}{$\begin{array}{c}\begin{array}{c}\text { Pathogen-associated } \\
\text { molecular patterns } \\
\text { (PAMPs) }\end{array} \\
\text { Mannans }\end{array}$} \\
\hline CLRs & DC-SIGN & & \\
\hline & Dectin1 & Macrophage & $\beta$-1,3-glucan \\
\hline & Dectin2 & $\begin{array}{l}\text { Macrophage } \\
\text { Neutrophil } \\
\text { DCs }\end{array}$ & $\alpha$-mannans \\
\hline & MINCLE & $\begin{array}{l}\text { Monocyte } \\
\text { Neutrophil }\end{array}$ & $\alpha$-mannosyl residues \\
\hline & $\begin{array}{l}\text { Mannose } \\
\text { receptor }\end{array}$ & Macrophage & N-mannan \\
\hline \multirow[t]{4}{*}{ TLRs } & TLR2 & Monocyte & O-mannan \\
\hline & TLR4 & Monocyte & O-mannan \\
\hline & TLR9 & $\begin{array}{l}\text { Monocyte } \\
\text { Macrophage }\end{array}$ & Unmethylated DNA \\
\hline & TLR3 & $\begin{array}{l}\text { Monocyte } \\
\text { Macrophage }\end{array}$ & Double-stranded RNA \\
\hline \multirow[t]{2}{*}{ NLRs } & NOD2 & Monocyte & Chitin \\
\hline & NLRP3 & Monocyte & $\beta$-1,3-glucans \\
\hline \multirow[t]{2}{*}{ Other receptors } & Galectin 3 & Macrophage & $\beta$-mannan \\
\hline & EphA2 & Epithelial cells & $\beta$-glucan \\
\hline
\end{tabular}

mainly consists of keratinocytes. The outermost epithelium layer comprises several layers of closely arranged cells known as the stratum corneum, which can be divided into orthokeratosis and parakeratosis. C. albicans infection mainly causes epithelial surface edema. Hyphae are found in the outer $1 / 3$ of the keratinized layer or epithelium and are vertically distributed on the epithelial surface, with several neutrophil infiltrations. Hyphae and infiltrated inflammatory cells form microabscesses. Besides, there are several lymphocytes, plasma cells, neutrophils, and other inflammatory cells in the connective tissue below the epithelium. Many immune cells participate in the antifungal process during C. albicans infections (Figure 2).

\section{Epithelial Cells}

Epithelial cells are essential in mucosal immunity against fungal invasion. C. albicans hyphae invade the epithelial cells via the active penetration and the induced endocytosis processes (Naglik et al., 2011; Mayer et al., 2013). The two processes involve specific pathogen-associated molecular patterns (PAMPs), expressed on the fungal surface, and recognition by pattern recognition receptors (PRRs) of host cells (Mogensen, 2009; AmaranteMendes et al., 2018). The PRR family members include Toll-like receptors (TLRs), C-type lectin receptors (CLRs), and NODlike receptors (NLRs) (Netea et al., 2008; Brown, 2011; Gow et al., 2011; Wheeler et al., 2017; Heung, 2020; Pellon et al., 2020; Vendele et al., 2020). Several TLRs are found on the mucosal epithelial cell surface, of which TLR4 directly affects the mucosal defense against $C$. albicans infection (Weindl et al., 2007; Naglik and Moyes, 2011). The epithelial ephyrin type-A receptor 2 (EphA2) was recently identified as a nontraditional PRR involved in C. albicans cell wall component and $\beta$-glucan identification (Swidergall et al., 2018; Swidergall et al., 2019; Olsen, 2020). This recognition is non-specific, and 


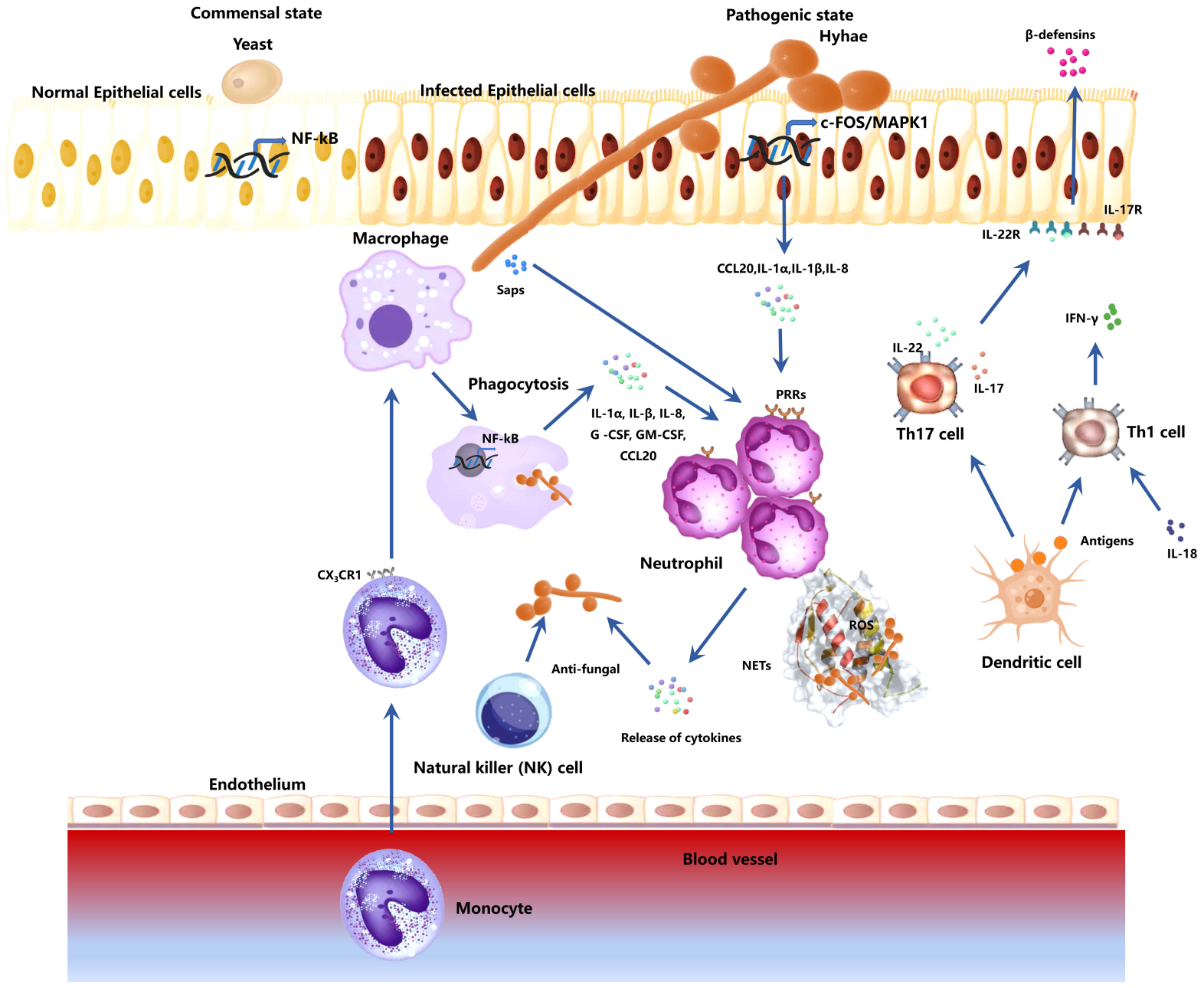

FIGURE 2 | Responses of host immune-related cells during C. albicans mucosa invasion. The fungus transforms from a commensal to a pathogenic state by first breaking through the epithelial cells. Epithelial cells activate mitogen-activated protein kinase 1 (MAPK1)- and FOS-related pathways to mediate cytokine production (CCL20, IL-1 $\alpha, I L-1 \beta, I L-8)$. These cytokines can recruit host immune cells. Epithelial cells also release $\beta$-defensins for anti-candida activities. The macrophages in the tissue contribute to the antifungal effect through phagocytosis and secretion of cytokines (IL-1 $\alpha$, IL- $\beta$, IL-8, G-CSF, GM-CSF, CCL20). Monocytes in the blood are recruited. They migrate to the infected sites, differentiate into macrophages, and participates in anti-C. albicans process. Neutrophils respond to cytokines secreted by macrophages and epithelial cells, and fungal antigenic substances Saps. Neutrophil activation induces the production of active antifungal substances to kill the fungi. Neutrophil can also release neutrophil extracellular traps (NETs) and reactive oxygen species (ROS) to kill the C. albicans, which cannot be engulfed due to the large hyphae. DC cells activate Th cells via antigen presentation. Th17 activation induces IL-17 and IL-22 production, which are involved in the recruitment and activation of neutrophils. IL-17 and IL-22 can also activate epithelial cells and promote the release of -defensins. Activated Th1 cells can secrete IFN- $\gamma$, promoting neutrophil and macrophage antifungal effects. NK cells also have a certain resistance to C. albicans hyphae.

both C. albicans hyphae and yeast can be identified. Besides C. albicans, other fungal species can induce EphA2 activation. However, EphA2 activation via C. albicans is the most researched (Dambuza and Brown, 2018). A study showed that fungi invasion (oral candidiasis) was significantly high in the EphA2 $2^{-/-}$ knockout mice with normal immune function than WT mice (Swidergall et al., 2018). Upon detecting abnormal morphology and proliferation of $C$. albicans, the epithelial cells activate the internal mitogen-activated protein kinase 1 (MAPK1) and FOS pathway (Moyes et al., 2010; Moyes et al., 2011). The activated epithelial cells release various pro-inflammatory cytokines and immune cell chemokines to recruit more immune cells to reach the infected area, thus improving immune response. The released cytokines include interleukin-1 $\alpha$ (IL-1 $\alpha)$, interleukin$1 \beta$ (IL-1 $\beta$ ), interleukin-8 (IL-8), and chemokine (C-C motif) ligand 20 (CCL20) (Moyes and Naglik, 2011; Swidergall et al., 2018). Epithelial cells can also produce antifungal $\beta$-defensins through response activation to IL-22 produced by Th17 cells, inhibiting C. albicans invasion (Eyerich et al., 2011; Sparber and LeibundGut-Landmann, 2019; Gaffen and Moutsopoulos, 2020). The latest research shows that IL-22 and IL-17 have a synergistic effect against $C$. albicans. Therefore, IL-22 signaling activation is 
essential in the oral basal epithelial layer and can cooperate with IL-17 signaling in the oral mucosa (Aggor et al., 2020).

\section{Macrophages}

The macrophages are the key effector cells in the antifungal mucosal defense (Hirayama et al., 2017) and kill C. albicans mainly via phagocytosis (Uwamahoro et al., 2014). The effector cells have phagosomes containing enzymes that can produce reactive oxygen species (ROS) and reactive nitrogen species (RNS) (Nüsse, 2011; Uribe-Querol and Rosales, 2017). C. albicans are phagocytized into macrophages, where they are constricted in the phagosomes and killed via ROS (Uwamahoro et al., 2014). Macrophages produce chemokines and inflammatory factors, which recruit and activate other immune cells to the infection sites. A study showed that proliferation and lethality of C. albicans are significantly higher in macrophages-deficient mice than in normal mice (Qian et al., 1994; Wheeler et al., 2017). Meanwhile, blood monocytes move to the infected site, differentiating into inflammatory macrophages for the anti-infection process (Serbina et al., 2008). The $\mathrm{CX}_{3} \mathrm{C}$-chemokine receptor $1\left(\mathrm{CX}_{3} \mathrm{CR} 1\right)$ on the macrophage surface is essential in the resistance process to candidiasis (Lee et al., 2018). These results show the role of macrophages in mucosal fungal infection defense.

\section{Neutrophils}

Neutrophils are essential in Candida mucosal infection defense. Neutrophils respond to chemokines released by the activated epithelial cells and macrophages, such as IL-1 $\alpha$, IL- $\beta$, IL8, G -CSF, GM-CSF, CCL20, and $\beta$ defensin, then moves to the fungal infected tissues (Netea et al., 2008; Moyes et al., 2016; Patin et al., 2019; Pellon et al., 2020). Neutrophils can also directly respond to the C. albicans virulence factors, such as the secretory aspartyl proteinases (Saps) (Gabrielli et al., 2016; Singh et al., 2020). Neutrophils are essential in antifungal mucosal immunity. Neutropenia greatly increases the risk of invasive fungal infections (Kullberg et al., 1990; Horn et al., 2009; Hirayama et al., 2020). Neutrophils are the only host cell that can successfully inhibit $C$. albicans transformation from the yeast phase to the hyphae phase (Brown, 2011; Lionakis, 2014). A mouse neutropenia model revealed severe fungal infections (Kullberg et al., 1990). Several PRRs on neutrophil surface, including TLR2, TLR4, TLR9, Dectin-1, Dectin-2, Dectin-3, DC-SIGN, and MINCLE, can recognize C. albicans antigenic components (Taylor et al., 2007; Cheng et al., 2012; Zhu et al., 2013; Dühring et al., 2015) thus complete neutrophil activation (Cheng et al., 2012; Kenny et al., 2017; Li et al., 2020). The activated MyD88, inflammatory complex, and SYK can mediate the downstream MAPK and NF- $\mathrm{BB}$ signaling pathways in neutrophils, leading to the expression of cytokines and antifungal factors, such as elastase, lactoferrin, $\beta$-defensin, lysozyme, gelatinase, and cathepsin G (Amulic et al., 2012; Liew and Kubes, 2019). Neutrophil elastase and cathepsin B also have antifungal activity (McCormick et al., 2010; Shopova et al., 2020). Besides, the phagocytosis and the unique role of neutrophil extracellular traps (NETs) are activated in neutrophils (Cheng et al., 2012; Menegazzi et al., 2012; Kenny et al., 2017). The neutrophils also phagocytize C. albicans through the PRRs on the cell surface. For instance, the neutrophils kill C. albicans through an oxidative cell reaction (Aratani et al., 2002; Endo et al., 2017) after C. albicans recognition via Dectin-1 (Netea et al., 2015). Besides C. albicans, Dectin-1 also recognizes $\beta$-glucans in the cell wall of many fungal species. The neutrophil cells kill non-phagocytized-C. albicans hyphae via NETs (Urban et al., 2006; Menegazzi et al., 2012; Halverson et al., 2015). NETs, formed by several DNA-containing fibril structures, can combine the pathogens and induce the production of antimicrobial substances, such as myeloperoxidase (MPO), lactoferrin, azurocidin, and cathelicidin, for antifungal activity (Urban et al., 2009; McCormick et al., 2010; Papayannopoulos, 2018). Calprotectin is an essential NET (Urban et al., 2009). Protease 3 can hydrolyze cathelicidin to antimicrobial peptide LL-37 (CAMP) (Kościuczuk et al., 2012), which has several antimicrobial effects. CAMP promotes the destruction of the fungal cell membrane by directly binding to the fungus (Zhang et al., 2010; Kahlenberg and Kaplan, 2013), inhibit biofilm formation and fungal adhesion (Tsai et al., 2011), enhancing the production of chemotaxis and ROS, and inhibiting neutrophil apoptosis (Nagaoka et al., 2006; Alalwani et al., 2010). Although both the yeast and hyphal forms of $C$. albicans trigger NETs, neutrophils respond faster to hyphae. Besides killing fungi directly, NETs can slow the hyphae growth, possibly by limiting micronutrients, such as zinc (Urban et al., 2009).

\section{Natural Killer (NK) Cells}

Natural killer cells are essential in innate immunity against fungal invasion (Schmidt et al., 2018). Existing studies mainly focus on the role of NK cells in systemic Candida infection, and none has reported its functions in mucosal infections. Studies have shown systemic candidiasis mouse models without NK cells have increased sensitivity to the Candida spp. and Aspergillus spp. (Whitney et al., 2014; Drummond and Lionakis, 2019). A Similarly, in severe combined immunodeficiency disease (SCID) mice with lymphocyte deficiency, NK cell depletion increases sensitivity to systemic candidiasis (Quintin et al., 2014). NK cells promote immune activation of epithelial cells and phagocytic cells, limiting invasion and spread of Candida from the mucosal surface to the deeper layers. Although NK cells cannot inhibit the Candida hyphae growth, they significantly affect perforin-dependent antifungal activity (Voigt et al., 2014; Abel et al., 2018). NK cells also have similar roles in Candida mucosal infections. However, more evidence is needed to confirm the roles of NK cells in mucosal fungal infection.

\section{Dendritic Cells (DCs)}

The host can produce IFN $\beta$ through SYK- and IFN-regulatory factor 5 (IRF5)-dependent pathway, which has an anticandidiasis effect. Dendritic cells (DCs) are essential during this process (Biondo et al., 2011; del Fresno et al., 2013; Hoepel et al., 2019). DCs mainly recognize antigenic substances in the internal environment and present to T cells (Steinman, 2012). Although DCs are not as effective at Candida phagocytosis as macrophages, their antigen presentation role in activating Th cells is crucial (Ramirez-Ortiz and Means, 2012; Richardson and Moyes, 2015). 


\section{T Cells}

Many specific $\mathrm{T}$ cells are involved in inhibiting Candida infections (Verma et al., 2014). Studies have shown that Candidaspecific T cells can produce IL-17 and IFN- $\gamma$ against Candida infections (Zielinski et al., 2012; Conti et al., 2016; Verma et al., 2017; McDermott and Klein, 2018). Both Th1 and Th17 are essential in Candida infection defense (Conti and Gaffen, 2015; Speakman et al., 2020). Furthermore, Th1 cell response and IFN $-\gamma$ production are essential during neutrophil and macrophage inhibiting processes against fungal invasion (Netea et al., 2015; Dewi et al., 2017). IL-18 induces Th1 cell activation (Netea et al., 2003; Nakanishi, 2018). A study showed that mice without IFN- $\gamma$ and IL-18 are more prone to candidiasis. However, IFN- $\gamma$ or IL-18 treatment reverses the susceptibility (Stuyt et al., 2004). Th17 cells are also essential in the resistance process to C. albicans (Hernández-Santos and Gaffen, 2012). Th17 cells produce IL-17 and IL-22, which are involved in the recruitment and activation of neutrophils (Liang et al., 2006). Th17 cells can also activate epithelial cells, which produce $\beta$ defensins (Eyerich et al., 2011). Recently, studies have proved that Th17 cell response is essential in human anti-mucosal fungal infections (Hernández-Santos and Gaffen, 2012; Mengesha and Conti, 2017). A study showed that mice without IL-17 receptor or downstream signaling elements are more sensitive to oropharyngeal candidiasis (Conti et al., 2016). Several immune cells, including $\gamma \delta$-T cells, NK cells, type 3 innate lymphoid cells (ILC3), and TCR $\beta$ + "natural" Th17 cells (nTh17), produce IL-17 (Conti and Gaffen, 2015).

\section{Functions of Th17/IL-17}

The stabilization, degradation, and translation of mRNA are regulated by IL-17, orchestrated by a suite of RNA binding proteins, including Act1. This property of IL-17 explains how it can synergize with a wide range of inflammatory signals. Besides, most of the relevant RNA binding proteins were first identified in studies of IL-17-dependent oral candidiasis (Li et al., 2019). IL-17 can regulate different immune relevant factors, including neutrophil-activating CXC chemokines and G-CSF, antimicrobial $\beta$-defensins proteins, cytokines (IL-6 and GM$\mathrm{CSF}$ ), and transcription factors ( (Li et al., 2019). Consistently, IL-17/Th 17 drives potentially damaging inflammation (Stockinger and Omenetti, 2017). Th17 responses are significant in the protection against $C$. albicans (Li et al., 2018). Besides providing protective immunity, Th17 cells contribute to immune pathology. C. albicans-specific $\mathrm{T}$ cell responses broadly modulate human anti-fungal Th17 immunity by propagating Th17 cells cross-reactive to other fungal species, such as Aspergillus fumigatus. This could accentuate acute allergic bronchopulmonary aspergillosis (Bacher et al., 2019). However, IL-17 also drives tissue repair. Barrier tissue repair tends to be the dominant response in the gut (Hueber et al., 2012; Stockinger and Omenetti, 2017). The degree to which IL-17 drives tissue repair in the oral mucosa is poorly understood (Li et al., 2019). Disease-associated fungi trigger IL-6- and IL-23-dependent accumulation of Th17 cells on the oral mucosa. Disease-causing Th17 cells drive tissue damage through excessive neutrophil recruitment and related immunopathology (Dutzan et al., 2017). Meanwhile, C. albicans hyphae secrete the peptide candidalysin, which damages oral epithelial cells and triggers the secretion of IL-1 and IL-36. These signals activate innate IL-17-producing cells. IL-17 binds to its receptor on oral epithelial cells and induces the release of antimicrobial effectors, including CXC chemokines and G-CSF. These effectors promote a neutrophil response and direct fungicidal activity (Huppler et al., 2014; Trautwein-Weidner et al., 2015; Conti et al., 2016). Based on the double-edged functions of Th17 cells, which besides protecting barrier tissues, contribute to immunopathology, the importance of Th17/IL-17 in controlling antifungal response remains controversial (Gaffen and Moutsopoulos, 2020).

\section{ALBICANS ESCAPE MECHANISMS}

C. albicans has several mechanisms for escaping host immune detection and elimination. For instance, hyphae elongation hinders phagocytic activity or damage phagocytic cells, triggering stress response pathways in fungi and interfering with phagosome maturation.

\section{Phagocytosis Evasion by Changing Cell Size and Shape}

Various phagocytic cells have a conventional cell size, limiting the size of the microorganisms they can engulf. For instance, C. albicans has a diameter of between 5 and $10 \mu \mathrm{m}$ in the yeast phase and over $20 \mu \mathrm{m}$ in the hyphal phase (Bar-Yosef et al., 2017; Mukaremera et al., 2017), indicating that phagocytosis cannot occur in the latter stage. Conversely, the fungus can perforate the phagocytic cells due to its increased growth rate, thus killing the phagocytic cell (Lewis et al., 2012). Although the $\mathrm{RAB}$ protein regulates phagosome maturation in phagocytic cells, C. albicans cell wall morphogenesis can prevent phagosome death by interfering with the RAB protein role of phagosome maturation (Alvarez-Dominguez et al., 2008; Kopeckova et al., 2020). Studies have shown that RAB14 localizes to C. albicans phagosomes after phagocytosis. RAB14 localization is associated with the morphology of the fungal cells in the phagosome and the size of the hyphae. Loss of RAB14 function delays phagolysosome maturation, increasing C. albicans escaping rate and macrophage killing rate (Okai et al., 2015).

\section{Prevention of Identification and Killing by Changing C. albicans Cell Wall Structure}

The host enzyme effect and free radical activation trigger fungi cell wall stress sensors. The sensors activate the Mkc1 pathway, leading to Rlm1-dependent activation of chitin which can strengthen cell wall biosynthesis and repair cell wall damages (Fuchs and Mylonakis, 2009; Román et al., 2015). C. albicans cell wall composition also affects the function of phagosomeassociated RAB protein (Lewis et al., 2012). For instance, mannan loss increases the phagosome function and reduces the ability of fungi to escape the host immune. Mannan has a protective effect on $\beta$-glucan, which prevents the exposure and identification of fungal antigens in phagocytic cells (Snarr et al., 2017). 


\section{Prevention of Immune Killing by Activating C. albicans Stress Response Pathways}

The intracellular phagosomes mainly kill the fungal cells after C. albicans endocytosis in phagocytic cells. Phagosomes contain several antimicrobial agents, such as hydrolases and oxidants, which can kill and degrade C. albicans cells (Flannagan et al., 2009). Studies have shown that NADPH oxidase activity is associated with fungal oxidative damage, limiting Candida cell growth (Brothers et al., 2013; Alves et al., 2020). However, C. albicans responds to these stresses mainly through the stress pathways, including mitogen-activated protein kinase (MAPK) Hog1 (Enjalbert et al., 2006), AP1-like transcription factor Cap1, and heat shock transcription factor Hsfl (da Silva Dantas et al., 2010). ROS and RNS activate the expressions of the transcription factors Cap1 and Cta4, inducing catalase, glutathione, and thioredoxin protective effects. However, removal of nitrous and oxidizing substances in immune cells induces protective effects of flavin hemoglobin Yhb1, thioredoxin, glutathione cycle enzymes glutathione reductase (Glr1), and S-nitrosoglutathione reductase (Fdh3) (Tillmann et al., 2015).

\section{Host Cell Death Induction}

C. albicans induces macrophage lysis, especially in the hyphal forms (Schäfer et al., 2014; Okai et al., 2015). C. albicans mutants without ergosterol cannot induce macrophage lysis, indicating that specific components of the fungal cell membrane are also necessary for macrophage lysis induction (O'Meara et al., 2015, 2018). Meanwhile, this lysis function is not associated with hyphae formation. Some mutants which can also form the hyphae, such as the ECE1 mutant, do not lyse macrophages (Kasper et al., 2018). The ECE1 gene encodes Candidalysin, a major C. albicans virulence factor, which damages cells by destroying the host cell membrane. The ECE1 null mutant also forms hyphae but cannot destroy cells (Moyes et al., 2016). Moreover, ALG1 and ALG11 mutants can also induce macrophage lysis without hyphae formation (O’Meara et al., 2015).

\section{OTHERS}

\section{Impact of Microbiome on the Outcome of Fungal Infection}

The human microbiota consists of bacteria, archaea, viruses, and fungi that build a highly complex network of interactions between each other and the host. C. albicans, as a commensal and opportunistic pathogen on the mucosa, often interact with other microbiota and work together to host immunity. C. albicans-specific Th17 cells can cross-react with A. fumigatus and contribute to pulmonary inflammatory diseases (Bacher et al., 2019). C. albicans and Staphylococcus aureus have a synergistic effect in mucosal infections (Li et al., 2018), with the former playing a leading role. Invasion and Th17 induction by $C$. albicans and $S$. aureus damage intestinal epithelial cells and release Th17-inducing cytokines (Moyes et al., 2016; Verma et al., 2017). However, some microbes resist C. albicans colonization. Commensal anaerobic bacteria, specifically clostridial Firmicutes (clusters IV and XIVa) and Bacteroidetes, are critical for maintaining C. albicans colonization resistance in mice (Fan et al., 2015). Hypoxia-inducible factor$1 \alpha$ (HIF-1 $\alpha)$, a transcription factor important for activating innate immune effectors, and the antimicrobial peptide LL37 (CRAMP in mice) are key determinants of this resistance effect (Fan et al., 2015). Understanding how other microbes and fungi interact to influence host health and immune modulation can lead to the development of therapeutic strategies aimed at preventing infection.

\section{Fungal Pathogens Modify/Interact With Epithelial and Immune Cells}

The host immune attack modifies itself in various ways to destroy fungal pathogens. Immune cells secreted proteins such as complement bind to fungal wall components, such as $\beta$ 1,6-glucan, resulting in enhanced phagocytosis (Rubin-Bejerano et al., 2007). In C. albicans, mannan protects $\beta$-glucan, preventing its exposure and identification. Host-derived immune cells release lytic enzymes to destroy the integrity and architecture of the fungal cell wall (Wheeler et al., 2008; Wagener et al., 2014). For different forms of fungi, host immune cells have devised specific response strategies to chemotactic signals released by hyphae (Jouault et al., 1998) while neutrophils migrate more rapidly toward yeast cells (Rudkin et al., 2013). This often leads to an increase in macrophage death (Rudkin et al., 2013). Besides, host phagocytes can exist with C. albicans without killing them or being killed by fungal lytic mechanisms (Bain et al., 2012). In mouse macrophages, actin and phosphoinositides are dynamically recruited to fully formed phagosomes containing C. albicans to prevent fungal escape (Heinsbroek et al., 2009). Although this mechanism can benefit host immune cells in avoiding lysis and death, it allows the fungus to spread to uninfected areas (Casadevall, 2010). Epithelial cells reply to C. albicans and candidalysin by activating epidermal growth factor receptor (EGFR) (Moyes et al., 2014). Inhibition of EGFR strongly suppresses candidalysin-induced MAPK signaling (cFos/MKP1) and GM-CSF and G-CSF release (Ho et al., 2019; Naglik et al., 2019). This impairs neutrophil recruitment (Liles et al., 1997; Gaviria et al., 1999) and amplifies C. albicans infections (Ho et al., 2019).

\section{OUTLOOK}

The microbial composition of the human mucosa is diverse and structurally complex. As the first line of defense for human immunity, the mucosa interacts with the microorganisms on its surface to keep the host healthy. However, C. albicans is the most prevalent fungus on the mucosa surface and causes numerous fungal diseases. The incidence of $C$. albicans infections has gradually increased due to the high occurrence of systemic diseases, such as tumors, Acquired Immune Deficiency Syndrome (AIDS), liver and kidney disorders, the widespread development of interventional therapy, organ transplantation, and the abuse of various antibiotics. The interaction between mucosal immunity and C. albicans involves many interconnected 
mechanisms, which can provide new drug candidate targets against $C$. albicans infection. The host immune regulation mechanism provides a basis for developing compounds that can activate specific host defenses, thus maximizing the killing of $C$. albicans and minimizing the damage to normal host cells. Furthermore, the self-protection mechanisms of C. albicans against the host immunity provide further information on how to effectively block the immune escape of C. albicans.

\section{AUTHOR CONTRIBUTIONS}

YZ, LC, YL, XZ, and BR: conception and design of the work and drafting the work. YZ, LC, and BR: revised the manuscript. $\mathrm{XZ}$ and $\mathrm{BR}$ : final approval

\section{REFERENCES}

Abel, A. M., Yang, C., Thakar, M. S., and Malarkannan, S. (2018). Natural killer cells: development, maturation, and clinical utilization. Front. Immunol. 9:1869. doi: 10.3389/fimmu.2018.01869

Aggor, F. E. Y., Break, T. J., Trevejo-Nuñez, G., Whibley, N., Coleman, B. M., Bailey, R. D., et al. (2020). Oral epithelial IL-22/STAT3 signaling licenses IL17-mediated immunity to oral mucosal candidiasis. Sci. Immunol. 5:eaba0570. doi: 10.1126/sciimmunol.aba0570

Alalwani, S. M., Sierigk, J., Herr, C., Pinkenburg, O., Gallo, R., Vogelmeier, C., et al. (2010). The antimicrobial peptide LL-37 modulates the inflammatory and host defense response of human neutrophils. Eur. J. Immunol. 40, 1118-1126. doi: 10.1002/eji.200939275

Alvarez-Dominguez, C., Madrazo-Toca, F., Fernandez-Prieto, L., Vandekerckhove, J., Pareja, E., Tobes, R., et al. (2008). Characterization of a Listeria monocytogenes protein interfering with Rab5a. Traffic 9, 325-337. doi: 10. 1111/j.1600-0854.2007.00683.x

Alves, R., Barata-Antunes, C., Casal, M., Brown, A. J. P., Van Dijck, P., and Paiva, S. (2020). Adapting to survive: how Candida overcomes host-imposed constraints during human colonization. PLoS Pathog 16:e1008478. doi: 10.1371/journal. ppat. 1008478

Amarante-Mendes, G. P., Adjemian, S., Branco, L. M., Zanetti, L. C., Weinlich, R., and Bortoluci, K. R. (2018). Pattern recognition receptors and the host cell death molecular machinery. Front. Immunol. 9:2379. doi: 10.3389/fimmu.2018.02379

Amulic, B., Cazalet, C., Hayes, G. L., Metzler, K. D., and Zychlinsky, A. (2012). Neutrophil function: from mechanisms to disease. Annu. Rev. Immunol. 30, 459-489. doi: 10.1146/annurev-immunol-020711-074942

Aratani, Y., Kura, F., Watanabe, H., Akagawa, H., Takano, Y., Suzuki, K., et al. (2002). Critical role of myeloperoxidase and nicotinamide adenine dinucleotide phosphate-oxidase in high-burden systemic infection of mice with Candida albicans. J. Infect. Dis. 185, 1833-1837. doi: 10.1086/340635

Arvanitis, M., and Mylonakis, E. (2015). Fungal-bacterial interactions and their relevance in health. Cell Microbiol. 17, 1442-1446. doi: 10.1111/cmi.12493

Awad, W. A., Hess, C., and Hess, M. (2017). Enteric pathogens and their toxininduced disruption of the intestinal barrier through alteration of tight junctions in chickens. Toxins (Basel) 9:60.

Bacher, P., Hohnstein, T., Beerbaum, E., Röcker, M., Blango, M. G., Kaufmann, S., et al. (2019). Human anti-fungal Th17 immunity and pathology rely on cross-reactivity against Candida albicans. Cell 176, 1340-1355.e15.

Bain, J. M., Lewis, L. E., Okai, B., Quinn, J., Gow, N. A., and Erwig, L. P. (2012). Non-lytic expulsion/exocytosis of Candida albicans from macrophages. Fungal Genet. Biol. 49, 677-678. doi: 10.1016/j.fgb.2012.01.008

Bar-Yosef, H., Vivanco Gonzalez, N., Ben-Aroya, S., Kron, S. J., and Kornitzer, D. (2017). Chemical inhibitors of Candida albicans hyphal morphogenesis target endocytosis. Sci. Rep. 7:5692.

Batbayar, S., Lee, D. H., and Kim, H. W. (2012). Immunomodulation of Fungal $\beta$ glucan in host defense signaling by Dectin-1. Biomol. Ther. (Seoul) 20, 433-445. doi: 10.4062/biomolther.2012.20.5.433 of the manuscript to be published. XZ, YL, and BR: agreement to be accountable for all aspects of the work. All authors contributed to the article and approved the submitted version.

\section{FUNDING}

This work was supported by the National Natural Science Foundation of China (Nos. 81870778, 81600858, and 81870759), Applied Basic Research Programs of Sichuan Province (No. 2020YJ0227 to BR), the Youth Grant of the Science and Technology Department of Sichuan Province, China (No. 2017JQ0028 to LC), and Innovative Research Team Program of Sichuan Province (LC).

Belkaid, Y., and Hand, T. W. (2014). Role of the microbiota in immunity and inflammation. Cell 157, 121-141. doi: 10.1016/j.cell.2014.03.011

Bihari, M., Srivastava, R., Jyoti, B., Mehrotra, V., Gupta, M., and Pradhan, S. (2014). Median rhomboid glossitis with palatal 'kissing lesion'-A case report. Bangladesh J. Dental Res. Educ. 4, 94-97. doi: 10.3329/bjdre.v4i2.20273

Biondo, C., Signorino, G., Costa, A., Midiri, A., Gerace, E., Galbo, R., et al. (2011). Recognition of yeast nucleic acids triggers a host-protective type I interferon response. Eur. J. Immunol. 41, 1969-1979. doi: 10.1002/eji.201141490

Branzk, N., Lubojemska, A., Hardison, S. E., Wang, Q., Gutierrez, M. G., Brown, G. D., et al. (2014). Neutrophils sense microbe size and selectively release neutrophil extracellular traps in response to large pathogens. Nat. Immunol. 15, 1017-1025. doi: 10.1038/ni.2987

Brothers, K. M., Gratacap, R. L., Barker, S. E., Newman, Z. R., Norum, A., and Wheeler, R. T. (2013). NADPH oxidase-driven phagocyte recruitment controls Candida albicans filamentous growth and prevents mortality. PLoS Pathog 9:e1003634. doi: 10.1371/journal.ppat.1003634

Brown, G. D. (2011). Innate antifungal immunity: the key role of phagocytes. Annu. Rev. Immunol. 29, 1-21. doi: 10.1146/annurev-immunol-030409-101229

Brown, G. D., Taylor, P. R., Reid, D. M., Willment, J. A., Williams, D. L., Martinez-Pomares, L., et al. (2002). Dectin-1 is a major beta-glucan receptor on macrophages. J. Exp. Med. 196, 407-412. doi: 10.1084/jem.20020470

Cambi, A., Netea, M. G., Mora-Montes, H. M., Gow, N. A., Hato, S. V., Lowman, D. W., et al. (2008). Dendritic cell interaction with Candida albicans critically depends on N-linked mannan. J. Biol. Chem. 283, 20590-20599. doi: 10.1074/ jbc.m709334200

Carolus, H., Van Dyck, K., and Van Dijck, P. (2019). Candida albicans and staphylococcus species: a threatening twosome. Front. Microbiol. 10:2162. doi: $10.3389 /$ fmicb. 2019.02162

Casadevall, A. (2010). Cryptococci at the brain gate: break and enter or use a Trojan horse? J. Clin. Invest. 120, 1389-1392. doi: 10.1172/jci42949

Chaffin, W. L., López-Ribot, J. L., Casanova, M., Gozalbo, D., and Martínez, J. P. (1998). Cell wall and secreted proteins of Candida albicans: identification, function, and expression. Microbiol. Mol. Biol. Rev. 62, 130-180. doi: 10.1128/ mmbr.62.1.130-180.1998

Cheng, S. C., Joosten, L. A., Kullberg, B. J., and Netea, M. G. (2012). Interplay between Candida albicans and the mammalian innate host defense. Infect. Immun. 80, 1304-1313. doi: 10.1128/iai.06146-11

Conti, H. R., Bruno, V. M., Childs, E. E., Daugherty, S., Hunter, J. P., Mengesha, B. G., et al. (2016). IL-17 receptor signaling in oral epithelial cells is critical for protection against oropharyngeal candidiasis. Cell Host Microbe 20, 606-617. doi: 10.1016/j.chom.2016.10.001

Conti, H. R., and Gaffen, S. L. (2015). IL-17-Mediated immunity to the opportunistic fungal pathogen Candida albicans. J. Immunol. 195, 780-788. doi: 10.4049/jimmunol.1500909

da Silva Dantas, A., Patterson, M. J., Smith, D. A., Maccallum, D. M., Erwig, L. P., et al. (2010). Thioredoxin regulates multiple hydrogen peroxide-induced signaling pathways in Candida albicans. Mol. Cell. Biol. 30, 4550-4563. doi: 10.1128/mcb.00313-10 
Dambuza, I. M., and Brown, G. D. (2018). Sensing fungi at the oral epithelium. Nat. Microbiol. 3, 4-5. doi: 10.1038/s41564-017-0086-2

Davidson, L., Netea, M. G., and Kullberg, B. J. (2018). Patient susceptibility to candidiasis-a potential for adjunctive immunotherapy. J. Fungi (Basel) 4:9. doi: 10.3390/jof 4010009

Davis, S. E., Hopke, A., Minkin, S. C. Jr., Montedonico, A. E., Wheeler, R. T., et al. (2014). Masking of $\beta(1-3)$-glucan in the cell wall of Candida albicans from detection by innate immune cells depends on phosphatidylserine. Infect. Immun. 82, 4405-4413. doi: 10.1128/iai.01612-14

del Fresno, C., Soulat, D., Roth, S., Blazek, K., Udalova, I., Sancho, D., et al. (2013). Interferon- $\beta$ production via Dectin-1-Syk-IRF5 signaling in dendritic cells is crucial for immunity to C. albicans. Immunity 38, 1176-1186. doi: 10.1016/j. immuni.2013.05.010

Dewi, I. M. W., Van De Veerdonk, F. L., and Gresnigt, M. S. (2017). The Multifaceted role of T-Helper responses in host defense against Aspergillus fumigatus. J. Fungi. (Basel) 3:55. doi: 10.3390/jof3040055

Drummond, R. A., and Lionakis, M. S. (2019). Organ-specific mechanisms linking innate and adaptive antifungal immunity. Semin. Cell Dev. Biol. 89, 78-90. doi: $10.1016 /$ j.semcdb.2018.01.008

Dühring, S., Germerodt, S., Skerka, C., Zipfel, P. F., Dandekar, T., and Schuster, S. (2015). Host-pathogen interactions between the human innate immune system and Candida albicans-understanding and modeling defense and evasion strategies. Front. Microbiol. 6:625. doi: 10.3389/fmicb.2015.00625

Dutzan, N., Abusleme, L., Bridgeman, H., Greenwell-Wild, T., Zangerle-Murray, T., Fife, M. E., et al. (2017). On-going mechanical damage from mastication drives homeostatic Th17 cell responses at the oral barrier. Immunity 46, 133-147. doi: 10.1016/j.immuni.2016.12.010

Endo, D., Fujimoto, K., Hirose, R., Yamanaka, H., Homme, M., Ishibashi, K. I., et al. (2017). Genetic phagocyte NADPH oxidase deficiency enhances nonviable Candida albicans-induced inflammation in mouse lungs. Inflammation 40, 123-135. doi: 10.1007/s10753-016-0461-9

Enjalbert, B., Smith, D. A., Cornell, M. J., Alam, I., Nicholls, S., Brown, A. J., et al. (2006). Role of the Hog1 stress-activated protein kinase in the global transcriptional response to stress in the fungal pathogen Candida albicans. Mol. Biol. Cell 17, 1018-1032. doi: 10.1091/mbc.e05-06-0501

Eyerich, S., Wagener, J., Wenzel, V., Scarponi, C., Pennino, D., Albanesi, C., et al. (2011). IL-22 and TNF- $\alpha$ represent a key cytokine combination for epidermal integrity during infection with Candida albicans. Eur. J. Immunol. 41, 1894-1901. doi: $10.1002 /$ eji.201041197

Fan, D., Coughlin, L. A., Neubauer, M. M., Kim, J., Kim, M. S., Zhan, X., et al. (2015). Activation of HIF-1 $\alpha$ and LL-37 by commensal bacteria inhibits Candida albicans colonization. Nat. Med. 21, 808-814. doi: 10.1038/nm.3871

Flannagan, R. S., Cosío, G., and Grinstein, S. (2009). Antimicrobial mechanisms of phagocytes and bacterial evasion strategies. Nat. Rev. Microbiol. 7, 355-366. doi: $10.1038 /$ nrmicro2128

Fuchs, B. B., and Mylonakis, E. (2009). Our paths might cross: the role of the fungal cell wall integrity pathway in stress response and cross talk with other stress response pathways. Eukaryot. Cell 8, 1616-1625. doi: 10.1128/ec.00193-09

Gabrielli, E., Sabbatini, S., Roselletti, E., Kasper, L., Perito, S., Hube, B., et al. (2016). In vivo induction of neutrophil chemotaxis by secretory aspartyl proteinases of Candida albicans. Virulence 7, 819-825. doi: 10.1080/21505594.2016.1184385

Gaffen, S. L., and Moutsopoulos, N. M. (2020). Regulation of host-microbe interactions at oral mucosal barriers by type 17 immunity. Sci. Immunol. 5:eaau4594. doi: 10.1126/sciimmunol.aau4594

Garcia-Rubio, R., De Oliveira, H. C., Rivera, J., and Trevijano-Contador, N. (2019). The fungal cell wall: candida, cryptococcus, and aspergillus species. Front. Microbiol. 10:2993. doi: 10.3389/fmicb.2019.02993

Gaviria, J. M., Van Burik, J.-A. H., Dale, D. C., Root, R. K., and Liles, W. C. (1999). Modulation of neutrophil-mediated activity against the pseudohyphal form of Candida albicans by granulocyte colony-stimulating factor (G-CSF) administered in vivo. J. Infect. Dis. 179, 1301-1304. doi: 10.1086/314728

Gazendam, R. P., Van Hamme, J. L., Tool, A. T., Van Houdt, M., Verkuijlen, P. J., Herbst, M., et al. (2014). Two independent killing mechanisms of Candida albicans by human neutrophils: evidence from innate immunity defects. Blood 124, 590-597. doi: 10.1182/blood-2014-01-551473

Gleiznys, A., Zdanavičiené, E., and Žilinskas, J. (2015). Candida albicans importance to denture wearers. a literature review. Stomatologija 17, $54-66$.
Gow, N. A., Van De Veerdonk, F. L., Brown, A. J., and Netea, M. G. (2011). Candida albicans morphogenesis and host defence: discriminating invasion from colonization. Nat. Rev. Microbiol. 10, 112-122. doi: 10.1038/nrmicro2711

Goyal, S., Castrillón-Betancur, J. C., Klaile, E., and Slevogt, H. (2018). The interaction of human pathogenic fungi with C-Type lectin receptors. Front. Immunol. 9:1261. doi: 10.3389/fimmu.2018.01261

Grice, E. A., and Segre, J. A. (2011). The skin microbiome. Nat. Rev. Microbiol. 9, 244-253.

Halverson, T. W., Wilton, M., Poon, K. K., Petri, B., and Lewenza, S. (2015). DNA is an antimicrobial component of neutrophil extracellular traps. PLoS Pathog 11:e1004593. doi: 10.1371/journal.ppat.1004593

Heinsbroek, S. E., Kamen, L. A., Taylor, P. R., Brown, G. D., Swanson, J., and Gordon, S. (2009). Actin and phosphoinositide recruitment to fully formed Candida albicans phagosomes in mouse macrophages. J. Innate Immun. 1, 244-253. doi: 10.1159/000173694

Hernández-Santos, N., and Gaffen, S. L. (2012). Th17 cells in immunity to Candida albicans. Cell Host Microbe 11, 425-435. doi: 10.1016/j.chom.2012.04.008

Heung, L. J. (2020). Monocytes and the host response to fungal pathogens. Front. Cell Infect Microbiol. 10:34. doi: 10.3389/fcimb.2020.00034

Hillman, E. T., Lu, H., Yao, T., and Nakatsu, C. H. (2017). Microbial ecology along the gastrointestinal tract. Microbes Environ. 32, 300-313. doi: 10.1264/jsme2. me17017

Hirayama, D., Iida, T., and Nakase, H. (2017). The phagocytic function of macrophage-enforcing innate immunity and tissue homeostasis. Int. J. Mol. Sci. 19:92. doi: 10.3390/ijms19010092

Hirayama, T., Miyazaki, T., Ito, Y., Wakayama, M., Shibuya, K., Yamashita, K., et al. (2020). Virulence assessment of six major pathogenic Candida species in the mouse model of invasive candidiasis caused by fungal translocation. Sci. Rep. 10:3814.

Ho, J., Yang, X., Nikou, S.-A., Kichik, N., Donkin, A., Ponde, N. O., et al. (2019). Candidalysin activates innate epithelial immune responses via epidermal growth factor receptor. Nat. Commun. 10:2297.

Hoepel, W., Newling, M., Vogelpoel, L. T. C., Sritharan, L., Hansen, I. S., Kapsenberg, M. L., et al. (2019). FcrR-TLR cross-Talk enhances TNF production by human monocyte-derived DCs via IRF5-Dependent gene transcription and glycolytic reprogramming. Front. Immunol. 10:739. doi: 10. 3389/fimmu.2019.00739

Hooper, L. V., Littman, D. R., and Macpherson, A. J. (2012). Interactions between the microbiota and the immune system. Science 336, 1268-1273. doi: 10.1126/ science. 1223490

Horn, D. L., Neofytos, D., Anaissie, E. J., Fishman, J. A., Steinbach, W. J., Olyaei, A. J., et al. (2009). Epidemiology and outcomes of candidemia in 2019 patients: data from the prospective antifungal therapy alliance registry. Clin. Infect. Dis. 48, 1695-1703. doi: $10.1086 / 599039$

Hueber, W., Sands, B. E., Lewitzky, S., Vandemeulebroecke, M., Reinisch, W., Higgins, P. D., et al. (2012). Secukinumab, a human anti-IL-17A monoclonal antibody, for moderate to severe Crohn's disease: unexpected results of a randomised, double-blind placebo-controlled trial. Gut 61, 1693-1700. doi: 10.1136/gutjnl-2011-301668

Huppler, A. R., Conti, H. R., Hernández-Santos, N., Darville, T., Biswas, P. S., and Gaffen, S. L. (2014). Role of neutrophils in IL-17-dependent immunity to mucosal candidiasis. J. Immunol. 192, 1745-1752. doi: 10.4049/jimmunol. 1302265

Iliev, I. D., Funari, V. A., Taylor, K. D., Nguyen, Q., Reyes, C. N., Strom, S. P., et al. (2012). Interactions between commensal fungi and the C-type lectin receptor Dectin-1 influence colitis. Science 336, 1314-1317. doi: 10.1126/ science. 1221789

Jang, J. H., Shin, H. W., Lee, J. M., Lee, H. W., Kim, E. C., and Park, S. H. (2015). An overview of pathogen recognition receptors for innate immunity in dental pulp. Med. Inflamm. 2015:794143.

Jouault, T., Fradin, C., Trinel, P. A., Bernigaud, A., and Poulain, D. (1998). Early signal transduction induced by Candida albicans in macrophages through shedding of a glycolipid. J. Infect. Dis. 178, 792-802. doi: 10.1086/515361

Kahlenberg, J. M., and Kaplan, M. J. (2013). Little peptide, big effects: the role of LL-37 in inflammation and autoimmune disease. J. Immunol. 191, 4895-4901. doi: 10.4049/jimmunol.1302005

Kasper, L., König, A., Koenig, P. A., Gresnigt, M. S., Westman, J., Drummond, R. A., et al. (2018). The fungal peptide toxin Candidalysin activates the NLRP3 
inflammasome and causes cytolysis in mononuclear phagocytes. Nat. Commun. 9:4260.

Kaufman, D., and Fairchild, K. D. (2004). Clinical microbiology of bacterial and fungal sepsis in very-low-birth-weight infants. Clin. Microbiol. Rev. 17, 638-680. doi: $10.1128 / \mathrm{cmr} \cdot 17.3 .638-680.2004$

Kenny, E. F., Herzig, A., Krüger, R., Muth, A., Mondal, S., Thompson, P. R., et al. (2017). Diverse stimuli engage different neutrophil extracellular trap pathways. eLife 6:e24437.

Khoury, Z. H., Vila, T., Puthran, T. R., Sultan, A. S., Montelongo-Jauregui, D., Melo, M. A. S., et al. (2020). The role of Candida albicans secreted polysaccharides in augmenting streptococcus mutans adherence and mixed biofilm formation: in vitro and in vivo studies. Front. Microbiol. 11:307. doi: 10.3389/fmicb.2020.00307

Kong, E. F., Tsui, C., Kucharíková, S., Andes, D., Van Dijck, P., and JabraRizk, M. A. (2016). Commensal protection of staphylococcus aureus against antimicrobials by Candida albicans biofilm matrix. mBio 7:e01365-16.

Kopeckova, M., Pavkova, I., and Stulik, J. (2020). Diverse localization and protein binding abilities of Glyceraldehyde-3-Phosphate dehydrogenase in pathogenic bacteria: the key to its multifunctionality? Front. Cell Infect Microbiol. 10:89. doi: $10.3389 /$ fcimb. 2020.00089

Kościuczuk, E. M., Lisowski, P., Jarczak, J., Strzałkowska, N., Jóźwik, A., Horbańczuk, J., et al. (2012). Cathelicidins: family of antimicrobial peptides. a review. Mol. Biol. Rep. 39, 10957-10970.

Krüger, W., Vielreicher, S., Kapitan, M., Jacobsen, I. D., and Niemiec, M. J. (2019). Fungal-Bacterial interactions in health and disease. Pathogens 8:70. doi: 10 . 3390/pathogens 8020070

Kühbacher, A., Burger-Kentischer, A., and Rupp, S. (2017). Interaction of Candida species with the skin. Microorganisms 5:32.

Kullberg, B. J., Van 'T Wout, J. W., and Van Furth, R. (1990). Role of granulocytes in increased host resistance to Candida albicans induced by recombinant interleukin-1. Infect. Immun. 58, 3319-3324. doi: 10.1128/iai.58.10.3319-3324. 1990

Lee, M., Lee, Y., Song, J., Lee, J., and Chang, S. Y. (2018). Tissue-specific role of CX(3)CR1 expressing immune cells and their relationships with human disease. Immune Netw 18:e5.

Lewis, L. E., Bain, J. M., Lowes, C., Gillespie, C., Rudkin, F. M., Gow, N. A., et al. (2012). Stage specific assessment of Candida albicans phagocytosis by macrophages identifies cell wall composition and morphogenesis as key determinants. PLoS Pathog 8:e1002578. doi: 10.1371/journal.ppat.1002578

Li, G., Fan, Y., Lai, Y., Han, T., Li, Z., Zhou, P., et al. (2020). Coronavirus infections and immune responses. J. Med. Virol. 92, 424-432.

Li, J., Casanova, J. L., and Puel, A. (2018). Mucocutaneous IL-17 immunity in mice and humans: host defense vs. excessive inflammation. Mucosal Immunol. 11, 581-589. doi: 10.1038/mi.2017.97

Li, X., Bechara, R., Zhao, J., Mcgeachy, M. J., and Gaffen, S. L. (2019). IL17 receptor-based signaling and implications for disease. Nat. Immunol. 20, 1594-1602. doi: 10.1038/s41590-019-0514-y

Liang, S. C., Tan, X. Y., Luxenberg, D. P., Karim, R., Dunussi-Joannopoulos, K., Collins, M., et al. (2006). Interleukin (IL)-22 and IL-17 are coexpressed by Th17 cells and cooperatively enhance expression of antimicrobial peptides. J. Exp. Med. 203, 2271-2279. doi: 10.1084/jem.20061308

Liew, P. X., and Kubes, P. (2019). The neutrophil's role during health and disease. Physiol. Rev. 99, 1223-1248.

Liles, W. C., Huang, J. E., Burik, J.-A. H. V., Bowden, R. A., and Dale, D. C. (1997). Granulocyte colony-stimulating factor administered in vivo augments neutrophil-mediated activity against opportunistic fungal pathogens. J. Infect. Dis. 175, 1012-1015. doi: 10.1086/513961

Lionakis, M. S. (2014). New insights into innate immune control of systemic candidiasis. Med. Mycol. 52, 555-564. doi: 10.1093/mmy/myu029

Lowman, D. W., Greene, R. R., Bearden, D. W., Kruppa, M. D., Pottier, M., Monteiro, M. A., et al. (2014). Novel structural features in Candida albicans hyphal glucan provide a basis for differential innate immune recognition of hyphae versus yeast. J. Biol. Chem. 289, 3432-3443. doi: 10.1074/jbc.m113. 529131

Mayer, F. L., Wilson, D., and Hube, B. (2013). Candida albicans pathogenicity mechanisms. Virulence 4, 119-128.

McCormick, A., Heesemann, L., Wagener, J., Marcos, V., Hartl, D., Loeffler, J., et al. (2010). NETs formed by human neutrophils inhibit growth of the pathogenic mold Aspergillus fumigatus. Microbes Infect. 12, 928-936. doi: 10.1016/j.micinf. 2010.06.009

McDermott, A. J., and Klein, B. S. (2018). Helper T-cell responses and pulmonary fungal infections. Immunology 155, 155-163. doi: 10.1111/imm.12953

Menegazzi, R., Decleva, E., and Dri, P. (2012). Killing by neutrophil extracellular traps: fact or folklore? Blood 119, 1214-1216. doi: 10.1182/blood-2011-07364604

Mengesha, B. G., and Conti, H. R. (2017). The role of IL-17 in protection against mucosal candida infections. J. Fungi. (Basel) 3:52. doi: 10.3390/jof3040052

Mogensen, T. H. (2009). Pathogen recognition and inflammatory signaling in innate immune defenses. Clin. Microbiol. Rev. 22, 240-273. doi: 10.1128/cmr. 00046-08

Montelongo-Jauregui, D., Saville, S. P., and Lopez-Ribot, J. L. (2019). Contributions of Candida albicans dimorphism, adhesive interactions, and extracellular matrix to the formation of dual-species biofilms with Streptococcus gordonii. mBio 10:e01179-19.

Moyes, D. L., Murciano, C., Runglall, M., Islam, A., Thavaraj, S., and Naglik, J. R. (2011). Candida albicans yeast and hyphae are discriminated by MAPK signaling in vaginal epithelial cells. PLoS One 6:e26580. doi: 10.1371/journal. pone. 0026580

Moyes, D. L., and Naglik, J. R. (2011). Mucosal immunity and Candida albicans infection. Clin. Dev. Immunol. 2011:346307.

Moyes, D. L., Runglall, M., Murciano, C., Shen, C., Nayar, D., Thavaraj, S., et al. (2010). A biphasic innate immune MAPK response discriminates between the yeast and hyphal forms of Candida albicans in epithelial cells. Cell Host Microbe 8, 225-235. doi: 10.1016/j.chom.2010.08.002

Moyes, D. L., Shen, C., Murciano, C., Runglall, M., Richardson, J. P., Arno, M., et al. (2014). Protection against epithelial damage during Candida albicans infection is mediated by PI3K/Akt and mammalian target of rapamycin signaling. J. Infect. Dis. 209, 1816-1826. doi: 10.1093/infdis/jit824

Moyes, D. L., Wilson, D., Richardson, J. P., Mogavero, S., Tang, S. X., Wernecke, J., et al. (2016). Candidalysin is a fungal peptide toxin critical for mucosal infection. Nature 532, 64-68. doi: 10.1038/nature17625

Mukaremera, L., Lee, K. K., Mora-Montes, H. M., and Gow, N. A. R. (2017) Candida albicans yeast, pseudohyphal, and hyphal morphogenesis differentially affects immune recognition. Front. Immunol. 8:629. doi: 10.3389/fimmu.2017. 00629

Nagaoka, I., Tamura, H., and Hirata, M. (2006). An antimicrobial cathelicidin peptide, human CAP18/LL-37, suppresses neutrophil apoptosis via the activation of formyl-peptide receptor-like 1 and P2X7. J. Immunol. 176, 30443052. doi: 10.4049/jimmunol.176.5.3044

Naglik, J. R., Gaffen, S. L., and Hube, B. (2019). Candidalysin: discovery and function in Candida albicans infections. Curr. Opin. Microbiol. 52, 100-109. doi: 10.1016/j.mib.2019.06.002

Naglik, J. R., and Moyes, D. (2011). Epithelial cell innate response to Candida albicans. Adv. Dent. Res. 23, 50-55. doi: 10.1177/0022034511399285

Naglik, J. R., Moyes, D. L., Wächtler, B., and Hube, B. (2011). Candida albicans interactions with epithelial cells and mucosal immunity. Microbes Infect. 13, 963-976. doi: 10.1016/j.micinf.2011.06.009

Nakanishi, K. (2018). Unique action of interleukin-18 on T cells and other immune cells. Front. Immunol. 9:763. doi: 10.3389/fimmu.2018.00763

Netea, M. G., Brown, G. D., Kullberg, B. J., and Gow, N. A. (2008). An integrated model of the recognition of Candida albicans by the innate immune system. Nat. Rev. Microbiol. 6, 67-78. doi: 10.1038/nrmicro1815

Netea, M. G., Joosten, L. A. B., Van Der Meer, J. W. M., Kullberg, B.-J., and Van De Veerdonk, F. L. (2015). Immune defence against Candida fungal infections. Nat. Rev. Immunol. 15, 630-642. doi: 10.1038/nri3897

Netea, M. G., Vonk, A. G., Van Den Hoven, M., Verschueren, I., Joosten, L. A., Van Krieken, J. H., et al. (2003). Differential role of IL-18 and IL-12 in the host defense against disseminated Candida albicans infection. Eur. J. Immunol. 33, 3409-3417. doi: 10.1002/eji.200323737

Nobile, C. J., and Johnson, A. D. (2015). Candida albicans biofilms and human disease. Annu. Rev. Microbiol. 69, 71-92.

Nüsse, O. (2011). Biochemistry of the phagosome: the challenge to study a transient organelle. ScientificWorldJournal 11, 2364-2381. doi: 10.1100/20 $11 / 741046$

Okai, B., Lyall, N., Gow, N. A., Bain, J. M., and Erwig, L. P. (2015). Rab14 regulates maturation of macrophage phagosomes containing the fungal pathogen 
Candida albicans and outcome of the host-pathogen interaction. Infect. Immun. 83, 1523-1535. doi: 10.1128/iai.02917-14

Oliveira-Nascimento, L., Massari, P., and Wetzler, L. M. (2012). The role of TLR2 in infection and immunity. Front. Immunol. 3:79. doi: 10.3389/fimmu.2012.00079

Olsen, I. (2020). Role of EphA2 in host defense against oro-pharyngeal candidiasis. J. Oral. Microbiol. 12:1711619. doi: 10.1080/20002297.2020.1711619

O'Meara, T. R., Duah, K., Guo, C. X., Maxson, M. E., Gaudet, R. G., Koselny, K., et al. (2018). High-Throughput screening identifies genes required for Candida albicans induction of macrophage pyroptosis. mBio 9:e01581-18.

O’Meara, T. R., Veri, A. O., Ketela, T., Jiang, B., Roemer, T., and Cowen, L. E. (2015). Global analysis of fungal morphology exposes mechanisms of host cell escape. Nat. Commun. 6:6741.

Papayannopoulos, V. (2018). Neutrophil extracellular traps in immunity and disease. Nat. Rev. Immunol. 18, 134-147. doi: 10.1038/nri.2017.105

Patil, S., Rao, R. S., Majumdar, B., and Anil, S. (2015). Clinical appearance of oral candida infection and therapeutic strategies. Front. Microbiol. 6:1391. doi: 10.3389/fmicb.2015.01391

Patin, E. C., Thompson, A., and Orr, S. J. (2019). Pattern recognition receptors in fungal immunity. Semin. Cell Dev. Biol. 89, 24-33. doi: 10.1016/j.semcdb.2018. 03.003

Patricia, P., José Artur, P., and Luís Miguel, B. (2019). Immune response in bacterial and Candida sepsis. Eur. J. Microbiol. Immunol. EJMI 9, 105-113. doi: 10.1556/ 1886.2019.00011

Patricio, P., Paiva, J. A., and Borrego, L. M. (2019). Immune response in bacterial and Candida Sepsis. Eur. J. Microbiol. Immunol. (Bp) 9, 105-113.

Pellon, A., Sadeghi Nasab, S. D., and Moyes, D. L. (2020). New insights in Candida albicans innate immunity at the mucosa: toxins, epithelium, metabolism, and beyond. Front. Cell Infect. Microbiol. 10:81. doi: 10.3389/fcimb.2020.00081

Peters, B. M., and Noverr, M. C. (2013). Candida albicans-Staphylococcus aureus polymicrobial peritonitis modulates host innate immunity. Infect. Immun. 81, 2178-2189. doi: 10.1128/iai.00265-13

Pincus, D. H., Orenga, S., and Chatellier, S. (2007). Yeast identificationpast, present, and future methods. Med. Mycol. 45, 97-121. doi: 10.1080/ 13693780601059936

Porcaro, I., Vidal, M., Jouvert, S., Stahl, P. D., and Giaimis, J. (2003). Mannose receptor contribution to Candida albicans phagocytosis by murine E-clone J774 macrophages. J. Leukoc. Biol. 74, 206-215. doi: 10.1189/jlb.1202608

Qian, Q., Jutila, M. A., Van Rooijen, N., and Cutler, J. E. (1994). Elimination of mouse splenic macrophages correlates with increased susceptibility to experimental disseminated candidiasis. J. Immunol. 152:5000.

Quintin, J., Voigt, J., Van Der Voort, R., Jacobsen, I. D., Verschueren, I., Hube, B., et al. (2014). Differential role of NK cells against Candida albicans infection in immunocompetent or immunocompromised mice. Eur. J. Immunol. 44, 2405-2414. doi: 10.1002/eji.201343828

Ramirez-Ortiz, Z. G., and Means, T. K. (2012). The role of dendritic cells in the innate recognition of pathogenic fungi (A. fumigatus, C. neoformans and C. albicans). Virulence 3, 635-646. doi: 10.4161/viru.22295

Richardson, J. P., and Moyes, D. L. (2015). Adaptive immune responses to Candida albicans infection. Virulence 6, 327-337.

Román, E., Alonso-Monge, R., Miranda, A., and Pla, J. (2015). The Mkk2 MAPKK regulates cell wall biogenesis in cooperation with the Cek1-Pathway in Candida albicans. PLoS One 10:e0133476. doi: 10.1371/journal.pone.0133476

Rubin-Bejerano, I., Abeijon, C., Magnelli, P., Grisafi, P., and Fink, G. R. (2007). Phagocytosis by human neutrophils is stimulated by a unique fungal cell wall component. Cell Host Microbe 2, 55-67. doi: 10.1016/j.chom.2007.06.002

Rudkin, F. M., Bain, J. M., Walls, C., Lewis, L. E., Gow, N. A., and Erwig, L. P. (2013). Altered dynamics of Candida albicans phagocytosis by macrophages and PMNs when both phagocyte subsets are present. mBio 4, $\mathrm{e} 00810-\mathrm{e} 00813$.

Saijo, S., Ikeda, S., Yamabe, K., Kakuta, S., Ishigame, H., Akitsu, A., et al. (2010). Dectin-2 recognition of alpha-mannans and induction of Th17 cell differentiation is essential for host defense against Candida albicans. Immunity 32, 681-691. doi: 10.1016/j.immuni.2010.05.001

Saijo, S., and Iwakura, Y. (2011). Dectin-1 and Dectin-2 in innate immunity against fungi. Int. Immunol. 23, 467-472. doi: 10.1093/intimm/dxr046

Salazar, F., and Brown, G. D. (2018). Antifungal innate immunity: a perspective from the last 10 years. J. Innate Immunity 10, 373-397. doi: 10.1159/000488539
Schäfer, K., Bain, J. M., Di Pietro, A., Gow, N. A., and Erwig, L. P. (2014). Hyphal growth of phagocytosed Fusarium oxysporum causes cell lysis and death of murine macrophages. PLoS One 9:e101999. doi: 10.1371/journal.pone.010 1999

Schmidt, S., Tramsen, L., Rais, B., Ullrich, E., and Lehrnbecher, T. (2018). Natural killer cells as a therapeutic tool for infectious diseases - current status and future perspectives. Oncotarget 9, 20891-20907. doi: 10.18632/oncotarget.25058

Serbina, N. V., Jia, T., Hohl, T. M., and Pamer, E. G. (2008). Monocyte-mediated defense against microbial pathogens. Annu. Rev. Immunol. 26, 421-452. doi: 10.1146/annurev.immunol.26.021607.090326

Shibata, N., Suzuki, A., Kobayashi, H., and Okawa, Y. (2007). Chemical structure of the cell-wall mannan of Candida albicans serotype A and its difference in yeast and hyphal forms. Biochem. J. 404, 365-372. doi: 10.1042/bj20070081

Shopova, I. A., Belyaev, I., Dasari, P., Jahreis, S., Stroe, M. C., Cseresnyés, Z., et al. (2020). Human neutrophils produce antifungal extracellular vesicles against Aspergillus fumigatus. mBio 11:e00596-20. doi: 10.1128/mBio.00596-20

Singh, D. K., Tóth, R., and Gácser, A. (2020). Mechanisms of pathogenic Candida species to evade the host complement attack. Front. Cell Infect. Microbiol. 10:94. doi: 10.3389/fcimb.2020.00094

Snarr, B. D., Qureshi, S. T., and Sheppard, D. C. (2017). Immune recognition of fungal polysaccharides. J. Fungi. (Basel) 3:47. doi: 10.3390/jof3030047

Souza, L. C. D., Mota, V., Carvalho, A., Corrêa, R., Libério, S. A., and Lopes, F. F. (2017). Association between pathogens from tracheal aspirate and oral biofilm of patients on mechanical ventilation. Braz Oral. Res. 31:e38.

Sparber, F., and LeibundGut-Landmann, S. (2019). Interleukin-17 in antifungal immunity. Pathogens 8:54. doi: 10.3390/pathogens8020054

Speakman, E. A., Dambuza, I. M., Salazar, F., and Brown, G. D. (2020). T Cell antifungal immunity and the role of C-Type lectin receptors. Trends Immunol. 41, 61-76. doi: 10.1016/j.it.2019.11.007

Steinman, R. M. (2012). Decisions about dendritic cells: past, present, and future. Annu. Rev. Immunol. 30, 1-22. doi: 10.1146/annurev-immunol-100311102839

Stockinger, B., and Omenetti, S. (2017). The dichotomous nature of T helper 17 cells. Nat. Rev. Immunol. 17:535. doi: 10.1038/nri.2017.50

Stuyt, R. J., Netea, M. G., Van Krieken, J. H., Van Der Meer, J. W., and Kullberg, B. J. (2004). Recombinant interleukin-18 protects against disseminated Candida albicans infection in mice. J. Infect. Dis. 189, 1524-1527. doi: 10.1086/382955

Swidergall, M., Solis, N. V., Lionakis, M. S., and Filler, S. G. (2018). EphA2 is an epithelial cell pattern recognition receptor for fungal $\beta$-glucans. Nat. Microbiol. 3, 53-61. doi: 10.1038/s41564-017-0059-5

Swidergall, M., Solis, N. V., Wang, Z., Phan, Q. T., Marshall, M. E., Lionakis, M. S., et al. (2019). EphA2 is a neutrophil receptor for Candida albicans that stimulates antifungal activity during oropharyngeal infection. Cell Rep. 28, 423-433.e5.

Taylor, P. R., Tsoni, S. V., Willment, J. A., Dennehy, K. M., Rosas, M., Findon, H., et al. (2007). Dectin-1 is required for beta-glucan recognition and control of fungal infection. Nat. Immunol. 8, 31-38. doi: 10.1038/ni1408

Thompson, A., Davies, L. C., Liao, C. T., Da Fonseca, D. M., Griffiths, J. S., Andrews, R., et al. (2019). The protective effect of inflammatory monocytes during systemic $C$. albicans infection is dependent on collaboration between C-type lectin-like receptors. PLoS Pathog 15:e1007850. doi: 10.1371/journal. ppat. 1007850

Tillmann, A. T., Strijbis, K., Cameron, G., Radmaneshfar, E., Thiel, M., Munro, C. A., et al. (2015). Contribution of Fdh3 and Glr1 to glutathione redox state, stress adaptation and virulence in Candida albicans. PLoS One 10:e0126940. doi: 10.1371/journal.pone. 0126940

Trautwein-Weidner, K., Gladiator, A., Nur, S., Diethelm, P., and LeibundgutLandmann, S. (2015). IL-17-mediated antifungal defense in the oral mucosa is independent of neutrophils. Mucosal Immunol. 8, 221-231. doi: 10.1038/mi. 2014.57

Trinchieri, G., and Sher, A. (2007). Cooperation of Toll-like receptor signals in innate immune defence. Nat. Rev. Immunol. 7, 179-190. doi: 10.1038/nri2038

Tsai, P. W., Yang, C. Y., Chang, H. T., and Lan, C. Y. (2011). Human antimicrobial peptide LL-37 inhibits adhesion of Candida albicans by interacting with yeast cell-wall carbohydrates. PLoS One 6:e17755. doi: 10.1371/journal.pone.0017755

Urban, C. F., Ermert, D., Schmid, M., Abu-Abed, U., Goosmann, C., Nacken, W., et al. (2009). Neutrophil extracellular traps contain calprotectin, a cytosolic protein complex involved in host defense against Candida albicans. PLoS Pathog 5:e1000639. doi: 10.1371/journal.ppat.1000639 
Urban, C. F., Reichard, U., Brinkmann, V., and Zychlinsky, A. (2006). Neutrophil extracellular traps capture and kill Candida albicans yeast and hyphal forms. Cell Microbiol. 8, 668-676. doi: 10.1111/j.1462-5822.2005.00 659.x

Uribe-Querol, E., and Rosales, C. (2017). Control of phagocytosis by microbial pathogens. Front. Immunol. 8:1368. doi: 10.3389/fimmu.2017.01368

Uwamahoro, N., Verma-Gaur, J., Shen, H.-H., Qu, Y., Lewis, R., Lu, J., et al. (2014). The pathogen \&lt;span class=\&quot;named-content genus-species\&quot; id=\&quot;named-content-1\&quot;\&gt;Candida albicans\&lt;/span\&gt; Hijacks Pyroptosis for Escape from Macrophages. mBio 5:e00003-14.

van Bruggen, R., Drewniak, A., Jansen, M., Van Houdt, M., Roos, D., Chapel, H., et al. (2009). Complement receptor 3, not Dectin-1, is the major receptor on human neutrophils for beta-glucan-bearing particles. Mol. Immunol. 47, 575-581. doi: 10.1016/j.molimm.2009.09.018

van de Veerdonk, F. L., Marijnissen, R. J., Kullberg, B. J., Koenen, H. J., Cheng, S. C., Joosten, I., et al. (2009). The macrophage mannose receptor induces IL-17 in response to Candida albicans. Cell Host Microbe 5, 329-340. doi: 10.1016/j.chom.2009.02.006

Vendele, I., Willment, J. A., Silva, L. M., Palma, A. S., Chai, W., Liu, Y., et al. (2020). Mannan detecting C-type lectin receptor probes recognise immune epitopes with diverse chemical, spatial and phylogenetic heterogeneity in fungal cell walls. PLoS Pathog 16:e1007927. doi: 10.1371/journal.ppat.1007927

Verma, A., Wüthrich, M., Deepe, G., and Klein, B. (2014). Adaptive immunity to fungi. Cold Spring Harb. Perspect. Med. 5:a019612.

Verma, A. H., Richardson, J. P., Zhou, C., Coleman, B. M., Moyes, D. L., Ho, J., et al. (2017). Oral epithelial cells orchestrate innate type 17 responses to Candida albicans through the virulence factor candidalysin. Sci. Immunol. 2:eaam8834. doi: 10.1126/sciimmunol.aam8834

Voigt, J., Hünniger, K., Bouzani, M., Jacobsen, I. D., Barz, D., Hube, B., et al. (2014). Human natural killer cells acting as phagocytes against Candida albicans and mounting an inflammatory response that modulates neutrophil antifungal activity. J. Infect. Dis. 209, 616-626. doi: 10.1093/infdis/jit574

Wagener, J., Malireddi, R. K., Lenardon, M. D., Köberle, M., Vautier, S., Maccallum, D. M., et al. (2014). Fungal chitin dampens inflammation through IL-10 induction mediated by NOD2 and TLR9 activation. PLoS Pathog 10:e1004050. doi: 10.1371/journal.ppat.1004050

Weindl, G., Naglik, J. R., Kaesler, S., Biedermann, T., Hube, B., Korting, H. C., et al. (2007). Human epithelial cells establish direct antifungal defense through TLR4-mediated signaling. J. Clin. Invest. 117, 3664-3672.

Wells, C. A., Salvage-Jones, J. A., Li, X., Hitchens, K., Butcher, S., Murray, R. Z., et al. (2008). The macrophage-inducible C-type lectin, mincle, is an essential component of the innate immune response to Candida albicans. J. Immunol. 180, 7404-7413. doi: 10.4049/jimmunol.180.11.7404

Wheeler, M. L., Limon, J. J., and Underhill, D. M. (2017). Immunity to commensal fungi: detente and disease. Annu. Rev. Pathol. 12, 359-385. doi: 10.1146/ annurev-pathol-052016-100342

Wheeler, R. T., Kombe, D., Agarwala, S. D., and Fink, G. R. (2008). Dynamic, morphotype-specific Candida albicans beta-glucan exposure during infection and drug treatment. PLoS Pathog 4:e1000227. doi: 10.1371/journal.ppat. 1000227

Whitney, P. G., Bär, E., Osorio, F., Rogers, N. C., Schraml, B. U., Deddouche, S., et al. (2014). Syk signaling in dendritic cells orchestrates innate resistance to systemic fungal infection. PLoS Pathog 10:e1004276. doi: 10.1371/journal.ppat. 1004276

Williams, D., and Lewis, M. (2011). Pathogenesis and treatment of oral candidosis. J. Oral. Microbiol. 3:5771. doi: 10.3402/jom.v3i0.5771

Yamasaki, S., Matsumoto, M., Takeuchi, O., Matsuzawa, T., Ishikawa, E., Sakuma, M., et al. (2009). C-type lectin mincle is an activating receptor for pathogenic fungus, malassezia. Proc. Natl. Acad. Sci. U S A. 106, 1897-1902. doi: 10.1073/ pnas.0805177106

Zhang, X., Oglęcka, K., Sandgren, S., Belting, M., Esbjörner, E. K., Nordén, B., et al. (2010). Dual functions of the human antimicrobial peptide LL-37-target membrane perturbation and host cell cargo delivery. Biochim. Biophys. Acta 1798, 2201-2208. doi: 10.1016/j.bbamem.2009.12.011

Zhu, L. L., Zhao, X. Q., Jiang, C., You, Y., Chen, X. P., Jiang, Y. Y., et al. (2013). C-type lectin receptors Dectin-3 and Dectin-2 form a heterodimeric patternrecognition receptor for host defense against fungal infection. Immunity 39, 324-334. doi: 10.1016/j.immuni.2013.05.017

Zielinski, C. E., Mele, F., Aschenbrenner, D., Jarrossay, D., Ronchi, F., Gattorno, M., et al. (2012). Pathogen-induced human TH17 cells produce IFN- $\gamma$ or IL-10 and are regulated by IL-1 $\beta$. Nature 484, 514-518. doi: 10.1038/nature10957

Conflict of Interest: The authors declare that the research was conducted in the absence of any commercial or financial relationships that could be construed as a potential conflict of interest.

Copyright (c) 2021 Zhou, Cheng, Lei, Ren and Zhou. This is an open-access article distributed under the terms of the Creative Commons Attribution License (CC BY). The use, distribution or reproduction in other forums is permitted, provided the original author(s) and the copyright owner(s) are credited and that the original publication in this journal is cited, in accordance with accepted academic practice. No use, distribution or reproduction is permitted which does not comply with these terms. 